binding of bilirubin to alhumin in vitro $(1,4,15,17)$ and in vivo (1). The fate of albumin-bound and lipid-associated bilirubin under these circumstances in vivo is currently under investigattion.

\section{RFFERI:N(ISS ANI) NOTIS}

1. Andrew, (i., (han, (i., and Schiff, 1).: I ipid metabolism in the neonate. II. The effect of Intralipid on bilirubin binding in vitre and in vivo. J. Pediat. si: $274(1976)$.

2. Borresen. H. C.. Coran, A. (;.., and knutsud, ().: Metabolic results of parenteral feeding in neonatal surgery. Amer. Surg., 172: 291 (1970)

3. Cashore, W. J., and Usher, R. H.: Intravenous nutrition of small premature infants. In: P. Hahn. S. Scgal, and S. Isratels: The Role of Fat in Intravenous Feeding of the Newborn, p. 122 (Pharmacia, Dorral, Quebec, 1974).

4. Chan, G., Schiff, D., and Stern, L.: Competitive hinding of free fatty acids and bilirubin to albumin: differences in H13 ABA deversus Sephadex ( $\mathrm{i}-25$ interpretation of results. (lin. Biochem. 4: 208 (1971).

5. Coran, $A$. ( $i .:$ The intravenous use of fat for the total parenteral nutrition of infants. I.ipids, 7: 455 (1972).

6. Coran, A. G., and Nesbakken, R.: The metabolism of intravenously administered fat in adult and newborn dogs. Surgery, 60 : $922(1969)$.

7. Gustafsen, A., Kjellmer. I.. Olegard, R., and Victorin, L. H.: Nutrition in low-birth-weight infants. II. Repeated intravenous injections of fat emulsion. Acta Pacdiat. Sciand., 0.3: 177 (197.4)

8. Kapoor, C. L., Krishna Murti, C. R., and Bajpai, P. C.: Uptake and release of bilirubin by skin. Biochem. J., 1.36: 35 (197.3).

9. Malloy, H. T., and Ivelyn, K. A.: The determination of bilirubin with the phole-clectric colorimeter. J. Biol. (hem., 119: 481 (1937).

10. Mustafi, M. G., and King. T. 1E.: Binding of bilirubin with lipid; a pousible mechanism of its toxic reactions in mitochondria. J. Bol. (hem., 245: 168.t (1970).

11. Ostrew, J. D., Hammaker, L... and Schmid, R.: The preparation of ervstaline bilirubin- ${ }^{14} \mathrm{C}$. J. Clin. Invest., 40 : 1442 (1961).

12. Pendray, 11. R.: Peripheral vein feeding in infants. In: P. Hahn. S. Sceal, and S. Israck: The Role of Fat in Intravenous Fecding of the Newborn. p. 158 (Pharmacia, Dorral, Quebec, 1974).

13. Schmid, R., Diamond, I., Hammaker, I... and (Bundersen, C. B.: Interaction of hilirubin with albumin. Niture, 206: 1041 (1965).

14. Schmid, R., and Hammaker, I... Metabolism and dispoxition of 't'(C-bilirubin in congenital non-hemolytic jaundice. J. Clin. Invest., 42: 1720 (1963).

15. Starinsky, R, and Shafrir, E.: Displatement of albumin-bound bilirubin by free fatty acids: Implications of neonatal hyperbilirubinemia. (lin. Chim. Acta, 24: 311 (1970).

16. Thaler, M. M., and Wennberg, R. P.: Influence of intravenous nutrients on hilirubin transport. II. Emulsificd lipid solutions. Pediat. Res., 11: 111 (1)77).

17. Thiessen. H., Jacoben, J., and Broklersen, R.: Displacement of albuminbound hilirubin by fatty acids. Actal Pacdiat. Scand., 61: 285 (1972).

18. Wolf, H., and Lohr, F.: Fettinfusionen bei frulechorenen am ersten lebenstag. M. Schr. Kinderlecilk, 1/6: 262 (1968).

19. Wretlint. O. A.: Complete intravenous nutrition: Theoretical and experimental background. Nutr. Metalol. Suppl., 14: 1 (1972).

20. Intralipid (available from Cutter I aboratories, Berkeley, (allif.) contains lo\%" soybean oil, $2.25 \%$ glycerin, and $1.2 r^{\prime}$ egg yolk phospholipids. The preparation provides $1.1 \mathrm{cil} / \mathrm{ml}$, and has an onmolality of $280 \mathrm{~m}() \mathrm{m} / \mathrm{litcr}$.

21. This rescarch was supported in part by National Institutes of Health (irant III)(13148 and United Cerchral Foundation (irant R-26.3-75.

22. Requests for reprints should be adesesed to: M. M. Thaler, M.D)., Department of Pediatrics, University of (alifornia, San Francisco, San Francisco, Calif. $9+1+3$ (USA).

23. Received for publication February 20, 1976.

24. Accepted for publication December 9, 1976.
Heart paramyxovirus lipids plasma membranes

\title{
A Biochemical Concept of Cellular Production of Paramyxoviruses
}

\author{
JOSEPH W. SI. GEMIE, JR.,"' HAWI.I:Y L. MARTIN, CATHLRINL IV. C. DAVIS. AND JAMES F. \\ MI:AD
}

Department of Pediatrics, Harbor General Hospital, UCLA School of Medicine, Torrance, California, and Department of Bioche'mistry, Center for the He'ulth Sciences, UCLA School of Medicince, Los Angeles, California,

USA

\section{Summary}

Previous analysis in vitro of the interaction between some paramyxoviruses and the chicken embryo has indicated that the cell most productive (NIP) of virus is the heart cell whereas the liver cell is least productive (LP). More superior production of virus results from more efficient release of virions, whereas the kinetics of viral attachment and penetration and the production of interferon are similar for both types of cell.

Since plasma membrane lipids may represent the structural key to enveloping and release of paramyxovirions, the lipid composition of MP and LP cells and purified plasma membranes was investigated. The plasma membranes of heart cells contain a high molar ratio of cholesterol to phospholipid (1.66 vs. 0.55$)$, more phosphatidylethanolamine $(34.8 \%$ vs. $24.0 \%$ of total phospholipid), and less phosphatidylcholine (39.7\% vs. $55.0 \%$ of total phospholipid) than the plasma membranes of liver cells. The fatty acids of heart and liver cellular plasma membranes are similar. The glycosphingolipid components of heart and liver cells are also the same, as is the content of gangliosides $(6.18 \mu \mathrm{g}$ vs. 6.49 $\mu$ g neuraminic acid/mg protein) in these cells, but the heart cell contains onc-fifth as much total cerebroside $(34.3 \mathrm{mg}$ vs. $174.3 \mu \mathrm{g}$ cerebroside/mg protein), indicating a greater ganglioside to neutral glycolipid ratio for the heart cell. Comparison of these data with the monkey/hamster (MP/L.P) renal cellparainfluenza SV5 virus system of Klenk and Choppin suggests that essential molecular determinants of superior cellular production of paramyxoviruses are the relative concentration of phosphatidylethanolamine and the molar ratio of cholesterol to phospholipid in the plasma membrane.

\section{Speculation}

The lipid composition of plasma membranes determines the capacity of host cells to assemble, envelop, and release para- 
myxoviruses. Consequently, certain organs may be characterized as high or low virus producers.

An experimental system of comparative tissue susceptibility to mumps virus has been developed in the chicken embryo and chicken embryonic cell cultures (4, 14). In ovo and in vitro, the most productive organ and culture is the heart and the least productive tissue is the liver. Approximately 10(0-fold more virus is found in heart tissue and heart cells produce 10 -fold more virus than liver cells. Other paramyxoviruses, parainfluenza virus types 1 and 3 , are also replicated maximally by heart cells (16). Analysis in vitro of the relative capability of heart and liver cells to produce mumps virus indicates that the early events of host cell-virus interaction, such as attachment and penetration, and the synthesis of interferon are similar for both cells; however, heart eells release virions more efficiently than liver cells (4).

A similar in vitro system of comparative susceptibility to another paramyxovirus, parainfluenza SV5 virus, has been described for monkey and hamster renal cells (9). Monkey cells produce $10(0$-fold more virions than hamster cells and ultrastructural studies indicate that viral nucleocapsid structures are moro actively enveloped and released at the plasma membrane (PM) of monkey cells (3). Biochemical evaluation of this renal cellparamyxovirus system disclosed that the PM's of the more competent monkey cell possess a different quantitative pattern of cholesterol, phospholipids, neutral glycolipids, and gangliosides than the membranes of hamster cells $(10-12)$.

Intrigued by the notion that the lipid composition of PM's may be a major important determinant of the relative capability of vertebrate tissues and cells to produce paramyxoviruses, we undertook similar bioclemical analyses of the PM's and whole cells of chicken embryonic heart and liver.

\section{METHODS}

\section{PRIPARATION OF PLASMA MIIMBRANIS AND WHOLE CIELLS}

Chicken embryonic heart and liver cells were cultivated from the organs of 17-day-old embryos. Utilizing trypsinization techniques described previously (4), 5 dozen eggs were sufficient to cultivate $4 \times 10^{4}$ cells from each organ in stationary bottles. Cultures were nourished for 1 week with replenishment of medium every $48 \mathrm{hr}$ to attiin optimal cell populations. Growth medium consisted of 90 parts Eagle's basal essential medium or minimal essential medium in Hanks' balanced salt solution and 10 parts bovine fetal serum or calf serum, supplemented by penicillin $(100 \mathrm{U} / \mathrm{ml})$, streptomycin $(100 \mu \mathrm{g} / \mathrm{ml})$, and sufficient sodium bicarbonate to provide pH 7.4. Twenty-four hours before monolayers were retrieved from flasks, serum was removed from the medium. After thorough rinse with $\mathrm{Ca}^{++}, \mathrm{Mg}^{++}$-free phosphatebuffered saline, cultures were treated for $20 \mathrm{~min}$ with $10 \mathrm{ml}$ deionized-distilled watter. Tris $(0.01 \mathrm{M})$-EDTA $(0.001 \mathrm{M}), \mathrm{pH}$

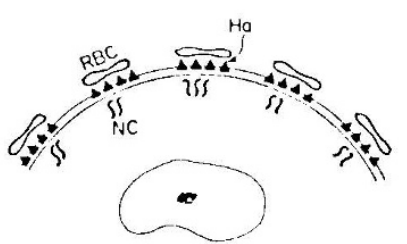

LP CELL

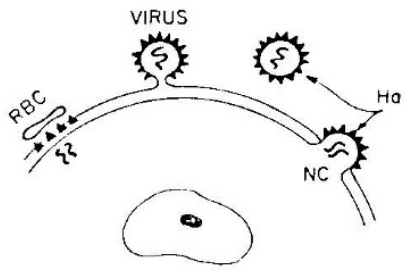

MP CELL
Fig. 1. Schematic characterization of the least productive (LP) and most productive $(M P)$ chicken embryonic eell infected with paramyxovirus. The LP cell contains viral nucleocapsid $(N C)$ beneath the plasma membrane and viral hemagglutinin $(H a)$ at the surface, the latter determined by adsorption of erythrocytes (RBC). The MP cell completes the process of viral maturation at the plasma membrane more efficiently, allowing budding and release of paramyxovirions.
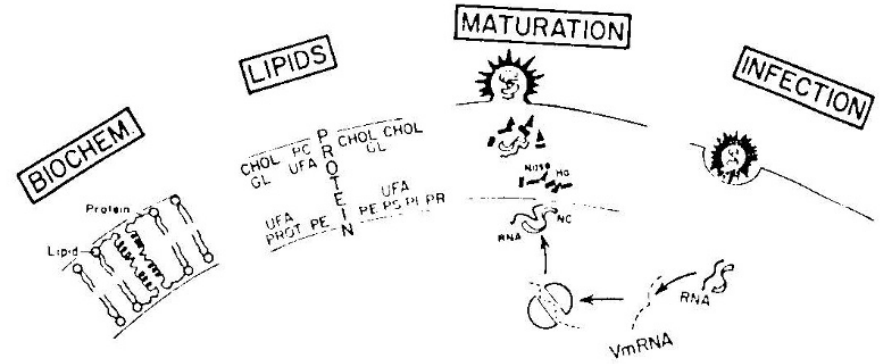

Fig. 2. Schematic characterization of the biochemical and virologic interrelationships in the plasma membrane of the most productive cell. Cholesterol $(C H O L)$, phosphatidylcholine $(P C)$, and glycolipids $(G L)$ constitute the major components of the external bilayer. Phosphatidylethanolamine $(P E)$, unsaturated fatty acids $(U F A)$, and protein $(P R O T, P R)$ are the major constituents of the inner layer, in addition to phosphatidylserine $(P S)$ and phosphatidylinositol $(P I)$. Following the carly biochemical events of infection and transcription of viral genome (RNA) to a positive strand messenger ( VmRNA) viral nucleocapsid (NC), hemagglutinin $(I I a)$, neuraminidase (Nase), and other structural proteins are synthesized. PE may promote the conformation of viral proteins within the plasma membrane and $\mathrm{CHOL}$ may seal the final assembly of viral components before extracellular release.

7.4. Was substituted for $30 \mathrm{~min}$ at room temperature and cells were removed by agitation of small glass beads over the surface of monolayers in small volumes of fresh EDTA solution. Cells were pelleted at $2,000 \mathrm{rpm}$ for $10 \mathrm{~min}$ in the cold and pooled. Adapting the method of Warren ct al. (21), cells were stirred in a saturated solution of fluorescein mercuric acetate, chilled over cracted ice, and disrupted with 10-20 gentle strokes in a Dounce homogenizer. Cell debris was suspended in cold $30 \%$ sucrose, layered over $45 \%$ sucrose, and centrifuged at $150 \times g$ for $1 \mathrm{hr}$ in the cold. The upper phase containing membranes and cell fragments wals removed, diluted, layered over fresh $45 \%$ suerose, and eentrifuged at $125 \times g$ for $1 \mathrm{hr}$. The upper layer was removed, layered over $35 \%$ sucrose, and the purified membranes were pelleted by centrifugation at $1,800 \times g$ for $2 \mathrm{hr}$. Successful purification of PM's was verified by phase and electron microscopy. Nembranes were refrigerated or lyophilized and frozen at $-70^{\circ}$ before lipid analysis. Heart and liver eells were equally susceptible to lysis and the subsequent harvest of membranes.

Because sucrose contamination of PM preparations precluded chromatographic separation of glycosphingolipids, in some experiments whole cells were harvested as above, suspended in chloroform-methanol (2:1), triturated with a TenBrock homogenizer, and analyzed for total neutral glycolipid and ganglioside content.

\section{LIPID ANALYSIS}

Preparations of PM's and whole cells were subjected to lipid extraction, homogenization, and filtration in chloroform-methatnol and the lipids were partitioned according to the method of lakomori and Murakami (7). Membrane preparations contained !-2 mg total lipid. Organic phase extracts were separated by silica gel chromatography into neutral lipid and neutral glyeolipid and phospholipid eluates. Neutral glycolipids and fatty acids were partitioned further by alkaline saponification and transmethylation (5). The ayueous phase of the initial extraction contained the polar glycolipids and was subjected to additional dialysis, lyophilization, and extraction in chloroform-methanol for analysis of gangliosides. Total lipids, cholesterol, and phospholipids were quantified by densitometric thin layer chromatography with charred copper acetate spray (6). Fatty acids were determined by gas chromatography. Neutral glycolipids and gangliosides were analyzed by thin layer chromatography using an orcinol spray. The relative concentration of glycolipidis and gangliosides of PM's and whole cells was assessed by the determina- 
Table 1. Lipid composition of plasma me'mbranes (P.M) and whole cells (WC) of chicken combryonic heart and liver

\begin{tabular}{|c|c|c|}
\hline & Heart & liver \\
\hline \multicolumn{3}{|l|}{ Total lipid. neutral lipid, and phospholipid (PM) } \\
\hline Neutritl lipid & $54.1^{1}$ & 48.9 \\
\hline Phospholipid & 45.9 & 51.1 \\
\hline Triglyceride & $11.0^{2}$ & +7.8 \\
\hline (holesterol & 73.4 & 31.5 \\
\hline Cholesterol ester & 10.1 & 16.4 \\
\hline Sphingomyclin & $5.9^{3}$ & 4.8 \\
\hline $\begin{array}{l}\text { Phosphatidylinesitol and phosphatidylser- } \\
\text { inc }\end{array}$ & 19.5 & 16.2 \\
\hline Phosphatidylcholine & 39.7 & 55.0 \\
\hline Phosphatidylethanolamine & 34.8 & 24.9 \\
\hline Molar ratio cholesterol: phospholipid & 1.66 & 0.5 .5 \\
\hline \multicolumn{3}{|l|}{ Fatty acids (PM1) } \\
\hline Palmitic & $25.9^{4}$ & 17.6 \\
\hline Palmitoleic & 4.5 & 2.6 \\
\hline Stcaric & 17.0 & 3.3 .0 \\
\hline Oleic & 22.4 & 22.3 \\
\hline Linoleic & 3.2 & 6.4 \\
\hline Arachiclonic & 2.8 & 7.5 \\
\hline \multicolumn{3}{|l|}{ Glycosphingolipid (WC) } \\
\hline Neutral glycolipid & $3+.3$ & 174.3 \\
\hline Gangliesicle & $6.18^{6}$ & 6.44 \\
\hline
\end{tabular}

'Neutral lipid and phospholipid data expressed as a percentage of total lipids.

2 Triglyceride, cholesterol, and cholesterol ester data expressed as at pereentage of total neutral lipids.

"Sphingomyelin, phosplatidylinositol, phosphatidylserine, phosphatidyleholine, and phosphatidylethandamine data expressed an a pereentage of total phospholipids.

${ }^{4}$ Datal expressed as a pereentage of total fatty acids.

s Micrograms of cerebroside per mg protein.

" Micrograms of neuraminic acid per mg protein.

tion of protein. neuraminic acid, and cerebroside in these preparations using the Lowry (13), thiobarbituric acid (21), and orcinol (20) techniques, respectively. The standards for these studies included CDH, CTH, globoside, gangliosides (G) $\mathrm{GA}_{2}, \mathrm{GM}_{3}$,

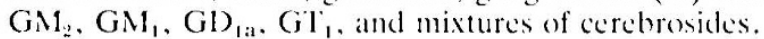

\section{RISULTS}

The data from one of three consistent experiments show a marked difference in the total lipid, neutral lipid, and phospholipid composition of the PNIs of chicken cmbryonic heart and liver cells (Table 1). The cholesterol level is substantially greater in heart cell Pils, as is the relative concentration of neutral lipids. The molar ratio of cholesterol to phospholipid is also greater in heart eell membranes. Although the distribution of sphingomyelin is similar for both cell types, heart cell membranes contain more phosphatidylethanolamine and phosphatidylinositol-phosphatidylserine and less phosphatidyleholine than liver cell membrames.

Two experiments were performed which revealed essentially identical data concerning the fatty acid composition of heart and liver cell PMls. The result of one of these experiments are shown in Table 1. Heart cell PNS contain more palmitic acid. nearly equivalent palmitoleic and oleic acid, and less stearic, linoleic, and arachidonic acid than liver cell membranes.

Thin layer chromatographic analysis of PNI preparations for their glycosphingolipid content proved difficult because of sucrose contamination and the inability to obtain clear separation of the neutral glycolipid and ganglioside components. Early results were clarified by subsequent chromatographic analysis of whole cell preparations. Qualitive study of chicken embryonic heart and liver cells disclosed the presence of the same neutral glycolipids (CDH, CIH, GA, and globoside) and gangliosides
$\left.\left(\mathrm{GM}_{2,}, \mathrm{GM}_{1} \text {, and } \mathrm{GI}\right)_{1: 1}\right)$ in both cells. Quantitative analysis of whole cell preparations revealed consistently more neutral glycolipid in liver cells than heart cells. In one representative experiment (Table 1), liver cells yickled $174.3 \mu \mathrm{g}$ cerebroside/ my protein whereas $34.3 \mu \mathrm{g}$ cerebroside/mg protein was recovered from heart cells. Similar concentrations of ganglioside were found in whole cell preparations of heart and liver, $6.18 \mu \mathrm{g}$ neuraminic acid/mg protein for heart cells and $6.49 \mu \mathrm{g}$ for liver cells. A solitary study of heart and liver cell P.M's revealed 3.9 $\mu$ mol neuraminic acid/mg protein for heart and $6.3 \mu \mathrm{mol}$ for liver.

\section{DISCUSSION}

We have shown that chicken embryonic heart and liver cells represent a cultural system of consistent, divergent competence to produce paramyxoviruses $(4,16)$. Moreover, in our original experiments with mumps virus in oro, this observation of differential susceptibility between the two tissues was exemplified by the discovery of $10(1-$ fold more virus and significant inflammatory pathology of the heart $(14,17)$. Heart cells are most productive (MP) of virus and liver cells leatst productive (LP), as judged by the capability of these cells to replicate greater or lesser amounts of virus in vitro (Fig. 1). The differential susceptibility is determined not by early afferent events of host cell/ virus interaction such as attachment and penetration but rather by the late enveloping and release of virions from the cell surface (4). Regulatory mechanisms, mediated by interferon, other noninterferon proteins, and the elaboration of defective-interfering virions, do not consistently explain the MP-LP cell phenomenon (15).

Two paramyxovirus-host ell systems have emerged which share biologic attributes. (One is the system which we have described and the other is the extensively studied system of Choppin and his colleagues (3.9). In their system, monticy renal cells are the MP cells for parainfluenza $S$ V 5 virus and hamster renal cells are the LP component. Klenk and Choppin (1i) advanced the concept that the lipid composition of the PMI may determine the more efficient enveloping and release of paramyxovirions by eertain cell populations, which we have arbitrarily labeled as the MP cell. The biologic similarity of the two systems offered a unique opportunity to solidify this biochemical concept. The chicken embryonic model represented an opportunity to explore an in vitro system with the compelling attributes of contrasting intraspecies organ performances and in vivo congruity.

Examining the PM neutral lipids and phospholipids of MP and I.P cells, we observed a very good fit between our data and that of Klenk and Choppin $(10,11)$, with particular emphatsis on the greater molar ratio of cholesterol to phospholipid in MP cell PMY and the fact that MP cell PM's contained more phosphatidylethanolamine and less phosphatidylcholine than LP cell membranes. The MP and I.P cell PNI fatty acids are also similar for both systems, with the notable exception of the highly unsaturated fatty acid, arachidonic acid. Arachidonic acid is proportionately greater in the monkey renal cell (MP) PM but proportionately lower in the heart cell (MP) PM. Qualitatively, reasonably similar neutral glycolipid and ganglioside components are found in the MP and LP cells of both systems (12). Our system contains two additional cerebrosides, $C D H$ and $\mathrm{GA}_{2}$, while both systems contain CTH and globoside. The renal cell system contains one different ganglioside, $\mathrm{BM}_{3}$, than the chicken embryonic cell system which contains GN.. Quantitatively, however, striking differences emerge. In the renal cell system, neutral glycolipids clearly predominate in the MP cell and gangliosides predominate in the L.P cell. In our system, neutral glycolipids predominate in the L.P cell and there is no consistent difference between the MP and I.P cell in ganglioside content.

Although a mechanistic explanation is unclear, these observations support the concept that the neutral lipid and phospholipid composition of cellular plasma membranes (Fig. 2) may be an 
essential determinant of the production of enveloping viruses by vertebrate tissues $(1,2,8,18,19)$.

\section{CONCLUSION}

Previous experiments have shown that chicken embryonic heart cells produce more paramyxovirions than chicken embryonic liver cells. Viral attachment and penetration and the elaboration of interferon are similar for both cell types. More efficient relcase of virions occurs in heart cells.

Analysis of total lipids, neutral lipids, and phospholipids of the plasma membranes of chicken embryonic heart and liver cells revealed a higher molar ratio of cholesterol to phospholipid. more phosphatidylethanolamine, and less phosphatidylcholine in heart cells. Plasma membrane fatty acids were similar. Analysis of the glycosphinogolipids of whole heart and liver cells disclosed a greater ratio of gangliosides to neutral glycolipids in heart cells.

These data support the notion that the relative concentration of phosphatidylethanolamine and the molar ratio of cholesterol to phospholipid in the plasma membrane may determine superior cellular production of paramyxoviruses.

\section{REFERENCES AND NOTIS}

1. Birdwell, C. R., and Stratuss, J. H.: Replication of Sindhis virus. IV. Electron microscope study of the insertion of viral glycoproteins into the surface of infected chick cells. J. Virol., 14: 366 (1974).

2. Bretscher, M. S.: Membrane structure: Some general principles. Science, 181 : $622(1973)$

3. Compans, R. W., Holmes, K. V., Dales, S., and Choppin, P. W.: An electron microscopic study of moderate and virulent virus-cell interactions of the parainfluenza virus SV5. Virology, 30): $411(19(26)$

4. Davis, C. W. C.. St. Geme, J. W.. Jr., Dufour, F. D., and Martin, H. L. Fxperimental avian viral myocarditis analyzed in vitro. J. Infect. Dis., I.32: $125(1975)$.

5. Fto, T., Ichikawa, Y., Nishimura, K., Ando, S., and Yamakawa, T.: Chemistry of lipid of the posthemolytic residue or stroma of erythrocytes. J. Biochem., 64: $205(1968)$.

6. Fewster, M. E., Burns, B. J., and Mead, J. F.: Ouantitative densitemetric thin-layer chromatography of lipids using copper acetate reagent. J. Chromatogr., 43: 120 (1969).

7. Hakomori, S. I., and Murakami, W. T.: (ilycolipids of hamster fibroblasts and derived malignant- transformed cell lines. Proc. Natl. Acad. Sci. U. S. A., 59: $254(1968)$.

8. Hirschberg, C. 13., and Robbins, P. W.: The glycolipids and phospholipids of
Sindbis virus and their relation to the lipids of the host cell plasma membrane. Virology, 61: 602 (1974).

9. Holmes, K. V., and Choppin, P. W.: On the role of the response of the cell membrane in determining virus virulence. J. Exp. Med., 124: 50! (1966).

10. Klenk, H. D., and Choppin, P. W.: Lipids of plasma membranes of monkey and hamster kidney cells and of parainfluenza virions grown in these cells. Virology, 38: 255 (1969).

11. Klenk, 11. D., and Choppin, P. W.: Plasma membrane lipids and parainflucnza virus asscmbly. Virology, 40: 939) (1970).

12. Klenk, H. D., and Choppin, P. W.: (jlycosphingolipids of plasma membranes of cultured cells and an enveloped virus (SV5) grown in these cells. Proc. Natl. Acad. Sci. U.S.A., 66: 57 (1970).

13. Lowry, O. H., Rosebrough, N. H.. Farr, A. I.., and Randall, R. J.: Protein measurement with the Folin phenol reagent. J. Biol. ('hem., 193: 265 (1951).

14. St. Geme, J. W., Jr., Davis, C. W. C., Peralta, H. J.. Farias, N. E., Yamauchi, T., and Cooper, M.D.: The biologic perturbations of persistent embryonic mumps virus infection. Pediat. Res., 7: 541 (1973).

15. St. Geme, J. W., Jr., and Martin, H. I..: Unpubiished datat.

16. St. Geme, J. W.. Jr., Martin, H. L., and Davis, C. W. C.: Comparative production of paramyxoviruses by avian heart cells. J. Gen. Virol., 25: 163 (1974).

17. St. (ieme, J. W., Jr., Peralta, H., Farias, E., Davis, C. W. C., and Noren, G. R.: Experimental gestational mumps virus infection and endocardial fibroelastosis. Pediatrics, 48: 821 (1971).

18. Singer, S. J., and Nicolson, G. L.: The fluid mositic model of the structure of cell membranes. Science, 175: 720 (1972).

19. Steinhart, W. L.. Ifogeman, C. S., and Powanda, M. C.: Inhibition of the production of infectious herpes simplex virus by clofibrate. Virology, 70: $241(1976)$.

20. Svennerholm, L.: The quantitative estimation of cerebrosides in nervous tissue. J. Neurochem., l: 42 (1956).

21. Warren, L.: The thiobarbituric acid assay of sialic acids. J. Biol. Chem., 234: 1971 (1959).

22. Warren, L., Glich, M. C., and Nass, M. K.: Membranes of animal cells. I. Methods of isolation of the surface membrane. J. Cell Physiol., 68: 269 (1966).

23. The authors wish to acknouledge the expert guidance, technical assistance, and generous donation of critical reagents by Drs. Rohert Neerhout, John Menkes, James Peter, and their laboratory staffs of the Departments of Pediatries, Neurology and Medicine. The Center for the Health Sciences, UCLA School of Medicine, and Dr. John O'Brien, Department of Neurosciences, University of California, San Diego School of Medicine. The final experiments were completed while the senior author was on sabbatical leave in the laboratery of Dr. John Holland, Department of Biology, University of California, San Diego. We wish to thank Mrs. Judy Liston for her skilled preparation of the manuscript.

24. Reguests for reprints should he addressed to: J. W. St. Geme, Jr., M.D Department of Pediatrics, Harbor General Hospital, UCLA School of Medicine, $10(\%)$ West Carson St., Turrance, Calif. 90509 (USA).

25. Received for publication January 14, 1976.

26. Accepted for publication September 2, 1976. 